\title{
How Has Malaysia Benefited from the High- Resolution Satellite Rainfall? Trends, Gaps and Further Research Opportunities
}

Mohd. Rizaludin Mahmud ${ }^{1,2^{*}}$, Fathiera Mansor ${ }^{2}$, Mohd. Afifi Md. Yatim², Aina Afifah Yusof ${ }^{2}$, Mohd. Nadzri Mohd. Reba ${ }^{1,2}$, Mazlan Hashim ${ }^{1,2}$, Masayu Norman³, Azimah Abd. Rahman4, Wan Shafrina Wan Mohd Jaafar5, Mohammad. Shawkat Hossein $^{6}$

${ }^{I}$ Faculty of Built Environment and Surveying, Universiti Teknologi Malaysia, 81310, Johor Bahru, MALAYSIA

${ }^{2}$ Geoscience \& Digital Earth Centre, Research Institute for Sustainable Environment, Universiti Teknologi Malaysia

${ }^{3}$ Dept. of Surveying Science and Geomatics, Faculty of Architecture, Planning, \& Surveying, Universiti Teknologi MARA Perlis, 02600, Arau, MALAYSIA

${ }^{4}$ School of Humanities, Universiti Sains Malaysia, 11800, Penang, MALAYSIA

${ }^{5}$ Earth Observation Centre, Institute of Climate Change, Universiti Kebangsaan Malaysia, 43600 Bangi, Selangor, MALAYSIA

${ }^{6}$ Institute of Oceanography and Environment (INOS), Universiti Malaysia Terengganu (UMT), 21030 Kuala Nerus, Terengganu, MALAYSIA

This paper presents a scientific review on how Malaysia has benefited from the high-resolution satellite rainfall since its first launch in 1998. As a tropical country in which the environment is highly characterised by rainfall dynamics, public domain access of high-resolution satellite rainfall data could be very useful to support the hydrologic and related environmental studies. The scope of this paper includes achievements, the trend of studies, as well as gaps and future opportunities for scientific research. Examining this element is crucial in determining the present information on the status quo of the applications of space-based technology to Malaysian hydrologic research. Furthermore, this information is critical to charter the future action for the policymakers and revision of respective disciplines, including climate change, environmental sustainability, disaster resilience, food security, and education. Based on the search throughout the largest scientific databases of Web of Science and Scopus, five major trends have been identified. Those trends were ranked based on the number of research, 1) Satellite rainfall data performance and quality evaluation (40\%), 2) Satellite rainfall data as input to environmental modelling $(27 \%)$, 3) Rain fade \& telecommunication (16\%), 4) Satellite rainfall data quality improvement (7\%), and 5) Rainfall studies. These trends were identified about 11 years after the satellite rainfall project started in 1998. The major achievement till now is validating the accuracy of the satellite rainfall and also downscaling it for local application.

Keywords: Tropical Rainfall Measuring Mission (TRMM); Global Precipitation Mission (GPM); hydrology; water 


\section{INTRODUCTION}

This paper provides a scientific review on how Malaysia had benefited from the high-resolution satellite rainfall since its launch in 1998. The launch of the high-resolution satellite rainfall of Tropical Rainfall Measuring Mission (TRMM) in 1998 remarks a new era of global hydrology, especially for/in the tropical region. With the new datasets that provide rainfall information at the finest spatial $\left(0.25^{\circ}\right)$ and temporal (3-hourly) scale ever, the TRMM data is expected to contribute significant knowledge and help in the advancement of the rainfall and related hydrological studies. Malaysia, as one of the countries in the tropical equatorial region with their climate and livelihood, is directly influenced by high dynamics rainfall and may benefit from these scientific advances to reach sustainable development. Therefore, reviewing the scientific achievements at the local scale is important in charting our way towards the future and what are the elements we should opt.

Although the early development of measuring rainfall from space has started in 1981where rainfall has been estimated using the cloud imageries from the MeteoSAT satellite, it did not reach the operational level until 1998. The limitation of the coarse and temporal resolution has been overcome by the Tropical Rainfall Measuring Mission (TRMM) project; a joint initiative by the National Aeronautics and Space Administration (NASA) and the Japan Aerospace Exploration Agency (Simpson et al., 1996). The satellite was specifically designed to study the precipitation that occurred within the tropics and subtropics region $\left(35^{\circ} \mathrm{N}\right.$ and $\left.35^{\circ} \mathrm{S}\right)$ from low orbit altitude about $237 \mathrm{~km}$. Theoretically, the TRMM satellite used an indirect approach to estimate the rainfall. The mechanism of TRMM to estimate the rainfall was driven by the active microwave precipitation radar (PR), TRMM microwave imager (TMI), and the visible, infrared scanner (VIRS) (NASDA, 2001). The reflected signals were empirically related to the rainfall values at the ground known as Z-R relationships (Iguchi et al., 2000).

The initiative by the Precipitation Processing System of NASA has created the much-sought operational data when combined with other meteorological satellites. At present, the TRMM based precipitation products were available at 3-hourly, daily and monthly scale. These datasets have supported significant scientific studies on tropical or sub- tropical rainfall at various scale and ecosystems (National Research Council of the National Academies, 2006). Before its success and the endeavour to ensure the longevity of their contribution, the project was succeeded by the Global Precipitation Mission satellite in 2014 (Hou et al., 2014). This new version of precipitation data has an improved spatial resolution of $0.1^{\circ}$ and half-hourly temporal resolution.

Although Malaysia has relatively good coverage of rain gauge distribution and effective weather radar monitoring systems provided by the respective agencies primarily the Department of Irrigation and Drainage and Malaysian Meteorological Department (Mahmud et al., 2014), the development of satellite rainfall which provides public access data with sound quality provides the researchers with ample opportunities to strengthen the existing systems. In this context, satellite rainfall data can be used as either substitute or back-up data in case of data conflict situation (DCS) which involved missing data condition, data sharing complexity, unknown quality of rainfall data and unavailable data condition. Hence, it is a known fact that climate change has impacted Malaysia either directly or indirectly via fluctuations in rainfall patterns (Zin et al., 2010; Tangang et al., 2013). Looking at the other tropical countries especially the developing ones which make use of this publicly free access satellite rainfall technology and data to their advantage, it is a wise and progressive action for researchers to emulate them. From a technical perspective, it provides an opportunity to learn the knowledge, science and engineering aspect in space application for weather and climate application in the tropical region. Who knows that in the future, we might be coordinating in those large scale projects or initiating our specific space weather programs that could benefit the regional community and spearheading new economic opportunities in local space sectors?

To address the aforementioned situation, this paper has set up two objectives; 1) search, analysed and systematically categorise the scientific research regarding the use of satellite rainfall in Malaysia and, 2) identify the subsequent gaps and future opportunities. Scholarly articles from the two largest scientific databases, Web of Science and Scopus from 1998 until 2018, were used. Among the primary reason for the selection of these two databases are to ensure the scientific soundness and relevance of the scholarly works. These two databases were strictly peer-reviewed by 
experts, and the total combined resources are large. Scopus database itself comprises 64 million articles, 21548 titles from about 5000 journals (Scopus, 2018). Web of Science, on the other hand, comprises nearly 90 million articles (Clarivate analytics, 2018). The output of this review should hopefully be able to track the trend on how Malaysia's benefited from one of the biggest global space science programs and assist the future strategy to optimise it.

\section{GENERAL TREND OF SATELLITE RAINFALL UTILISATION \& DEVELOPMENT IN MALAYSIA}

Based on the statistic shown in Figure 1, there were five major trends in the research and studies related to the use of high-resolution satellite rainfall in Malaysia.

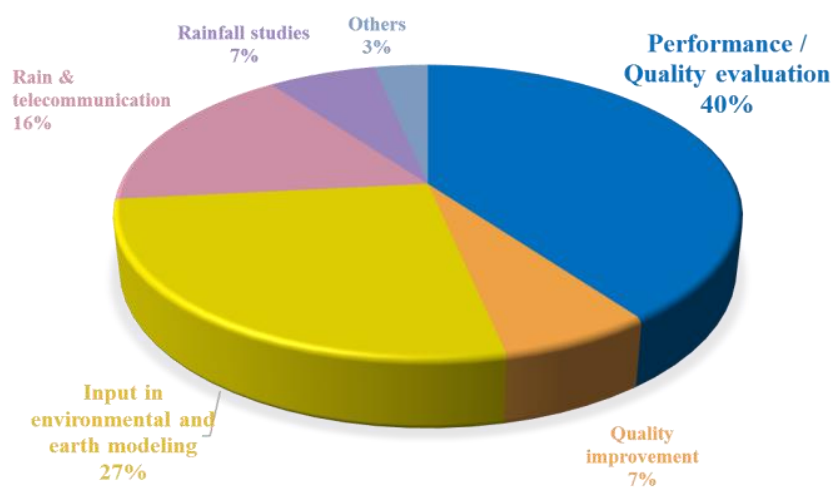

Figure 1. The trend of research and studies related to highresolution satellite rainfall in Malaysia

The five trends are; 1) performance and quality evaluation $(40 \%), 2)$ input to environment and earth modelling (27\%), 3) rain and telecommunication (16\%), 4) quality improvement (7\%), 5) rainfall studies (7\%) and others (3\%). From the temporal perspective, major trends for Malaysia started in 2010, although the earliest was identified in 2002. This means that the significant scientific contribution occurred about ten years after the data was first captured in 1998. Table 1 shows the five scientific trends occurred at a different rate in 20 years (1998-2018).

The first and second trends are more frequent than the others, since 2011. These two trends were more dominant and frequent compared to the other trend because of several factors. The first trend primarily influenced by the nature of the algorithm used to estimate the rainfall that was based on global datasets. Therefore, using it for the local environment might induce inaccuracy. Also, the lesson learnt from the previous studies related to satellite rainfall tends to highlight the necessity to determine the quality of the datasets at the local scale for better results (Huffman et al., 2005).

For the second trend, the stimulus was highly depending on the characteristics of the satellite rainfall which capable in providing the measurement of remote areas, at extensive coverage and reliable temporal scale (3 hourly to monthly). Because of this, the satellite rainfall data was significantly used as a substitute or supporting the in-situ measurement for regional analysis and areas which experienced in-situ data conflict situation (DCS) (Mahmud et al., 2018).

The third trend, which was more towards the application of satellite rainfall data to telecommunication engineering, was only active from 2011 to 2014. It was an obvious scientific fact that the frequency used in telecommunication, especially involving the $\mathrm{K}$ band was highly sensitive to water droplets. Because the satellite rainfall estimation was depending on the empirical relationship between the precipitable water and signal backscatter (Iguchi et al., 200ob), it does make sense that it was useful in telecommunication application. It provides information in knowing how severe the effects of the rain fade effects to telecommunication signals (ITU, 2015).

Following the gap identified by the first two trends, the fourth scientific research niche was focusing on quality improvement. The earliest works were identified in 2015, which focuses on reducing the quantitative rainfall estimation error during the heavy monsoon thunderstorm (Mahmud et al., 2015). Subsequent research then emphasised on the improvement of the spatial resolution where smaller gridded rainfall $(\sim 5 \mathrm{~km})$ was created (Mahmud et al., 2018). The downscaling was required because the catchment size in the humid tropics of Southeast Asia is relatively small, and its rainfall variation is highly dynamic. 
ASM Science Journal, Volume 12, 2019

Table 1. Scientific research utilising the high-resolution precipitation in Malaysia

\begin{tabular}{|c|c|c|c|c|c|c|c|c|c|c|}
\hline Topics / Year & 2002 & 2010 & 2011 & 2012 & 2013 & 2014 & 2015 & 2016 & 2017 & 2018 \\
\hline \multirow{3}{*}{$\begin{array}{l}\text { Performance / Quality } \\
\text { evaluation }\end{array}$} & & $\begin{array}{l}\text { Daily TRMM } \\
\text { rainfall } \\
\text { (Varikoden et } \\
\text { al.) }\end{array}$ & $\begin{array}{l}\text { Monthly TRMM } \\
\text { rainfall (Abiola et } \\
\text { al.) }\end{array}$ & $\begin{array}{l}\text { Monthly } \\
\text { TRMM } \\
\text { rainfall } \\
\text { (Semire et al.) }\end{array}$ & $\begin{array}{l}\text { Monthly } \\
\text { TRMM } \\
\text { rainfall } \\
\text { (Nadzri et al.) }\end{array}$ & $\begin{array}{l}\text { Minute TRMM rainfall } \\
\text { (Omotosho et al.) }\end{array}$ & $\begin{array}{l}\text { Monthly TRMM } \\
\text { rainfall (Semire } e t \\
\text { al.) }\end{array}$ & & $\begin{array}{l}\text { Daily rainfall TRMM } \\
\text { (Paska et al.) }\end{array}$ & $\begin{array}{l}\text { Daily rainfall } \\
\text { (Zad et al.) }\end{array}$ \\
\hline & & & & $\begin{array}{l}\text { Monthly } \\
\text { rainfall } \\
\text { (Huey and } \\
\text { Ibrahim) }\end{array}$ & & & $\begin{array}{l}\text { Seasonal TRMM } \\
\text { rainfall (Mahmud } \\
\text { et al.) }\end{array}$ & & $\begin{array}{l}\text { Multi-temporal } \\
\text { TRMM (Rauniyar et } \\
\text { al.) }\end{array}$ & \\
\hline & & & & & & & & & $\begin{array}{l}\text { Daily GPM (Mahmud } \\
\text { et al.) }\end{array}$ & \\
\hline Quality improvement & & & & & & & $\begin{array}{l}\text { Temporal } \\
\text { downscaling } \\
\text { (Mahmud et al.) }\end{array}$ & & & $\begin{array}{l}\text { Spatial } \\
\text { downscaling } \\
\text { (Mahmud et al.) }\end{array}$ \\
\hline \multirow[t]{3}{*}{$\begin{array}{l}\text { Input in environmental } \\
\text { modelling }\end{array}$} & & $\begin{array}{l}\text { Water balance } \\
\text { analysis (Sani et } \\
\text { al.) }\end{array}$ & $\begin{array}{l}\text { Forest water yield } \\
\text { (Mahmud and } \\
\text { Hashim) }\end{array}$ & & & $\begin{array}{l}\text { Surface water } \\
\text { (Ali et al.) }\end{array}$ & & $\begin{array}{l}\text { Forest ecology } \\
\text { assessment (Azmy } \\
\text { et al.) }\end{array}$ & & $\begin{array}{l}\text { Hydrology } \\
\text { modelling } \\
\text { (Ramli and } \\
\text { Ibrahim) }\end{array}$ \\
\hline & & $\begin{array}{l}\text { Forest water } \\
\text { yield (Mahmud } \\
\text { and Hashim) }\end{array}$ & & & & & & $\begin{array}{l}\text { Climatological } \\
\text { assessment } \\
\text { (Ibrahim et al.) }\end{array}$ & & \\
\hline & & & & & & & & $\begin{array}{l}\text { Surface run-off } \\
\text { (Hashim et al.) }\end{array}$ & & \\
\hline Rain \& communication & & & \multicolumn{4}{|c|}{$\begin{array}{c}\text { Rain fade in tropics } \\
\text { (Azlan et al.; Aris and Din; Yusuffet al.; Omotosho et al.) }\end{array}$} & & & & \\
\hline Rainfall studies & $\begin{array}{l}\text { Diurnal rainfall } \\
\text { characterisation at } \\
\text { synoptic regional } \\
\text { scale } \\
\text { (Soroshian et al.) }\end{array}$ & & & & & & $\begin{array}{l}\text { Seasonal and } \\
\text { diurnal variability } \\
\text { of rain height } \\
\text { (Isiaka and } \\
\text { Khamis) }\end{array}$ & & $\begin{array}{l}\text { Characterisation of } \\
\text { Sarawak daily rainfall } \\
\text { (Patrick et al.) }\end{array}$ & \\
\hline Others & & & & & & $\begin{array}{l}\text { Review for hilly } \\
\text { catchment (Mahmud et } \\
\text { al.) }\end{array}$ & & & & \\
\hline
\end{tabular}


Finally, the fifth trend, which involved studying the rainfall from space, had occurred occasionally in two periods, in 2002 and 2015-2017. Using the satellite rainfall data for rainfall or hydrometeorology analysis require less complex processing rather than modelling or calibrating, we hypothesised that this trend is getting greater attention just recently by the scientists and the community due to the availability of the data and advancement of the processing software. ESRI, for instance, evolved drastically in 2004 before the integration with ERDAS Imagine module (Smith, 2004). Furthermore, the open-source of cloud-based GIS system may also contribute to these trends (Sutton, 2009).

\section{ACHIEVEMENTS, GAPS \& OPPORTUNITIES}

\section{A. Trend 1 - Performance and Quality Evaluation}

The performance and quality evaluation primarily involved the quantitative accuracy of the rainfall estimates over local areas. Generally, a comparison against the rain gauges was conducted. It was quite difficult to define the consensus because the validation strategy and methodology were different from each other. These differences include the scale of rainfall, region of interest, the number of samples and techniques, however, were varied. In summary, all types of rainfall from minutes to annual scale have been conducted (Table 2).

Table 2. Summary of the performance and quality evaluation studies on satellite rainfall in Malaysia

\begin{tabular}{|l|l|l|c|c|c|c|c|c|}
\hline \multicolumn{1}{|c|}{ Source } & Data product & Technique & $\begin{array}{c}\text { No. of } \\
\text { stations }\end{array}$ & $\begin{array}{c}\text { Rainfall } \\
\text { scale }\end{array}$ & $\begin{array}{c}\text { Average } \\
\text { error }\end{array}$ & $\begin{array}{c}\text { Ratio } \\
(\%)\end{array}$ & $\begin{array}{c}\text { Correlation } \\
\text { NSE }\end{array}$ \\
\hline Varikoden et al., 2010 & TRMM 3B42 & Discrete comparison & 4 & 3 -hourly & - & 18 & 0.710 & - \\
\hline Abiola et al., 2011 & TRMM 3B43 & Discrete comparison & - & Monthly & - & 15 & 0.834 & - \\
\hline Semire et al., 2012 & TRMM 3B43 & Discrete comparison & 4 & Monthly & - & 15 & 0.871 & - \\
\hline $\begin{array}{l}\text { Huey and Ibrahim } \\
\text { 2012 }\end{array}$ & TRMM 3B43 & Discrete comparison & 24 & Annual & - & - & 0.623 & - \\
\hline Nadzri et al., 2013 & TRMM 3B43 & Discrete comparison & 26 & Monthly & $90 \mathrm{~mm} / \mathrm{mth}$ & - & - & 0.5 \\
\hline Omotosho et al., 2014 & TRMM 3B42 & Discrete comparison & 57 & Minute & $50 \mathrm{~mm} / \mathrm{min}$ & - & 0.700 & - \\
\hline Mahmud et al., 2015 & TRMM 3B43 & Interpolated surface & 984 & Seasonal & $100 \mathrm{~mm} / \mathrm{mth}$ & 50 & 0.7 & 0.5 \\
\hline Semire et al., 2016 & TRMM 3B43 & Discrete comparison & 5 & Monthly & - & - & 0.800 & - \\
\hline Paska et al., 2017 & TRMM 3B42 & Discrete comparison & 20 & Daily & - & - & 0.500 & - \\
\hline Rauniyar et al., 2017 & TRMM 3B42 & Discrete comparison & 49 & Daily & $5 \mathrm{~mm} / \mathrm{d}$ & 6 & 0.800 & - \\
\hline Patrick et al., 2017 & TRMM 3B42 & Discrete comparison & 25 & Daily & $140 \mathrm{~mm} / \mathrm{mth}$ & 17 & 0.800 & - \\
\hline Mahmud et al., 2017 & GPM Imerge & Interpolated surface & 843 & Daily & $20 \mathrm{~mm} / \mathrm{d}$ & - & 0.6 & - \\
\hline Zad et al., 2018 & TRMM 3B42 & Discrete comparison & 30 & Daily & - & 27 & 0.3 & - \\
\hline
\end{tabular}

It was proven that the satellite rainfall estimates were having different accuracy and performance via season and locations. Some consensuses that can be identified were the quantitative measurement during the heavy rainfall (Mahmud et al., 2015; Zad et al., 2018; Paska et al., 2017). Other significant information was that the correlation was better during the wet seasons (Semire et al., 2016; Mahmud et al., 2017; Patrick et al., 2017). It was indicated, however, that different evaluation method yields different results (e.g., Rauniyar et al., 2017).

Almost all of the validation works were conducted by referring to the ground rain gauges. Performing this famous methodology possesses limitation as mentioned by Mahmud et al. (2015); the different mechanism of rainfall measurement between those rain gauge and satellite precipitation radar. While rain gauge was measuring the 
amount of water trapped inside the gauge, the satellite precipitation radar estimates the rainfall based on the probable precipitable water in the atmosphere. The horizontal wind might cause the changes of rainfall pattern on the ground; hence commit uncertainties in the validation.

It was suggested that the alternative validation on satellite rainfall could be done with other devices which had a similar mechanism such as ground precipitation radar. If it is conducted simultaneously and using exact frequency, theoretically it could provide a more accurate justification on the performance and limitation of the satellite data performance at a local scale. For information, Malaysia did have their precipitation radar which operated by the Malaysian Meteorological Department. The biggest challenge could be dealing with the processing of the data, especially in term of adjusting the angle of propagation and projecting the images.

\section{B. Trend 2 - Input for Environmental Modelling}

The development for satellite rainfall utilisation in environmental modelling comprises two major spheres, 1) hydrological modelling and 2) ecological assessment. The exploitation of satellite rainfall data in hydrological modelling was intended in conducting a large scale or regional scale modelling (Ramli and Ibrahim, 2016; Ali et al., 2014; Sani et al., 2010; Hashim et al., 2016) and remote catchment (Mahmud and Hashim, 2010, 2011).

In general, despite reliable results given in all studies, it shared common problems; uncertainties during low rainfall season and large errors during heavy rain. Perhaps the next step in refining the modelling result is to carefully localise the satellite rainfall data especially when it involved quantitative hydrology such as run-off estimation and yield estimation.

In ecological assessment, satellite rainfall data is useful in studying the forest species adaptation towards the changing environment. Azmy et al. (2016) had successfully utilised the long-term rainfall and other meteorological data in identifying the early signals of dipterocarp reproductivity. On the other hand, Ibrahim et al. (2016) had investigated the relationship between rainfall, temperature and the El-
Nino Southern Oscillation. This shows that the satellite rainfall could be optimised to study the gap left by the limitation of rain gauges.

However, such studies were only reported in 2016. The TRMM has released the data in 2002. This means that the development of research areas that irrelevant to hydrology and water take longer time to advance in Malaysia. To encourage this multi-disciplinary trend to continue to evolve in the future, the gap of knowledge between the data scientist and the environmental scientist must be narrowed. Perhaps, the most effective ways to encourage such multidisciplinary studies is to establish an open-access satellite rainfall geodatabase with a user-friendly format; purposely to reduce data processing, retrieval and bureaucracy.

\section{Trend 3 - Quality Improvement}

This trend was the most recent to occur, plausibly due to the performance limitation found in the quality performance trend and during the direct forcing of satellite rainfall data for environmental modelling. There were two major types of quality improvement found, one is tackling the temporal deficiencies, and second is to improve the coarse grid of the satellite rainfall data. Since Malaysia is relatively a small region, improvement of spatial resolution is crucial, especially for catchment hydrology. The initial $0.25^{\circ}$ resolution of TRMM data tends to generalise the local scale rainfall pattern. The effort of using the seasonal monsoon co-efficient has successfully generated TRMM data with the highest resolution of $0.05^{\circ}$ (Mahmud et al., 2018).

The large quantitative error during heavy rainfall \& thunderstorm must be addressed in order to achieve accurate quantitative hydrologic modelling. Temporal downscaling algorithm using the PCA initiated by Mahmud et al. (2015) is effective during low rainfall $(<25 \mathrm{~mm} / \mathrm{d})$ and drought. Several innovative ideas that might be useful for quality improvement is to utilise topographic and orographic effect for mountainous catchment downscaling. It proved to be an effective method in sub-tropic and temperate climate condition (Jian et al., 2013; Chen et al., 2014). Another approach is to take advantage of the big 
geodata and advanced computer processing. With the aid of heavy computing, utilising the advanced computer learning algorithm such as support machine vector, machine learning and artificial network should be possible.

\section{Trend 4 - Rainfall Studies}

Despite the importance of rainfall studies for Malaysia and the novelty of satellite rainfall data to be used in hydrologic studies, the development in this area is relatively slow. The existing niche of studies involved utilisation of satellite rainfall data for rainfall analysis at synoptic scale (Sorooshian et al., 2002), the vertical profile of tropical rainfall (Isiaka and Khamis, 2015) and tropical storm in Sarawak (Patrick et al., 2017). This could be because of several factors, 1) data handling and processing, 2) satellite rainfall data theory and sciences, 3) restricted data access and 4) quality of research.

These challenges must be addressed in order to encourage the progress of hydrologic research utilising satellite rainfall data. The first and second challenges can be tackled by providing specific training by experts or experienced users. NASA currently offers satellite rainfall data in an openaccess database, which may address the third challenge. Challenge number four could be the hardest one. Identifying the scientific gaps that the conventional rain gauge or in-situ based measurement could not provide can be the key to improve the quality of research. If the strength of satellite rainfall and the missing elements in our understanding of local hydrology is carefully analysed, the focus should be put around the dynamic Spatio-temporal of tropical thunderstorm modelling.

\section{NEW NICHES OF INNOVATION AND DEVELOPMENT}

Based on the identified trend and scientific contributions above, we suggest that the new niche of research related to the utilisation of satellite rainfall data should emphasise in these four spheres of sciences, 1) strengthening the national hydrological framework, 2) social, culture, \& humanities, 3) tourism, and 4) environmental safety.

This public domain satellite rainfall data could play a significant role in strengthening the national hydrological framework. Firstly, it can be used as secondary data to evaluate the integrity of the existing rain gauge network data. Since the distribution of rain gauge is a laborious and tedious task, satellite data can be used as alternatives. It saves cost, time and tedious physical works. Secondly, it is useful for the source of rainfall data over sparse, ungauged and missing information areas or known as HDCS (hydrological data conflict situation) (Mahmud et al., 2018). Mountainous and high elevation, wetland and remote areas such as forest and large-scale plantations are mostly facing those constraints. Thirdly, satellite rainfall data could serve as useful data in creating a national high-resolution rainfall gridded network. Merging between rain gauge, satellite rainfall and ground precipitation radar is technically practical to be done in many developed countries, and the requirement for Malaysia is to have one particularly concerning a higher temporal scale framework, mainly hourly and daily. Availability of this data would benefit strategic economic and infrastructure planning, development and maintenance, as well as national safety towards environmental disasters, meteorological and environmental scientific research advancement and education.

Increasing the use of satellite rainfall data to study the impact of rainfall and its pattern, changes and evolution towards the social, culture and humanities are the next way forward to improve the adaptation of human to the environment. Rainfall played a significant role in the livelihood of the people. Therefore, by having effective spatial information of the rainfall over a substantial amount of time at various temporal scales, we could understand and further study our own social, culture and humanities evolution through time. Hence, it was considered as a crucial aspect in human development, capacity building and adaptation (Tait and Hanna, 2015). Climate change has been a prominent subject since a few decades, and since then, human adaptation to changing environment has been a priority for many countries (Frankhauser, 2016; Orlove, 2005).

Malaysia's ecotourism sites were mainly a rainfall-based environment or indirectly depending on rainfall to sustain its ecosystems. These include islands, waterfall, streams, 
rivers, and forest. Although substantial research can be found about the tourism potential of those ecosystems and its sustainability (Lee, 2013; Abdurahman et al., 2016), most are focusing at selected national parks with limited samples, and the covering was not spatially extensive. It leaves a big gap for the areas which do not have any in-situ rainfall measurement to be at least be supported by the satellite rainfall data.

The increased rainfall intensity, especially in urban areas of Malaysia, has increased the risk of safety. In the densely populated urban areas with complex road networks, heavy rain and thunderstorm could cause traffic congestions, slippery road, flash flood, and reduced visibility. Backcasting studies are important to determine the causal relationship and effective understanding of the past disaster for better future prevention. The new generation of satellite rainfall data product such as Global Precipitation Mission (GPM) and GsMAP provide high spatial resolution gridded rainfall up to $0.1^{\circ}(\sim 10 \mathrm{~km})$ could enable effective depiction of rainfall variation in urban areas. This is useful for the scientist to study the causal relationship between rainfall and the prospective disasters; and potentially identify risky areas for prevention, mitigation and assessment.

\section{FUTURE WORKS}

The trade-off of only considering the scientific papers from Web of Science and SCOPUS, which is lower in quantity and the covered niche was also limited. The main reason is to ensure that only significant scientific contribution was accounted for in the review. Studies published outside of WoS and SCOPUS including one that conducted at the undergraduate level, the non-indexed research publications, and the non-indexed conference proceedings provides merit in term of efforts by the scientific community; but pertaining issues of quality of the scientific works must be dealt with. It is also recommended that for the future work, scientific report by the local authorities or nongovernmental organisation (NGO) should be included. A better report on the satellite rainfall data usage and its peripherals issues can be chartered with the increased samples and careful evaluation of the novelty and scientific soundness of the scientific materials.

\section{REFERENCES}

[1] Abiola, SF, Mohd-Mokhtar, R, Ismail, W Mohamad, N, Mandeep, JS 2011, 'Satellite and ground data rainfall characterization in Malaysia', in 2011 IEEE International Conference on Space Science \& Communication: "Towards exploring the equatorial phenomena”, Proceedings 6015855, pp. $77-82$.

[2] Abdurahman, AZA, Ali, JK, Khedif, BLY, Bohari, Z, Ahmad, JA, Kibat, SA 2016, 'Ecotourism product attributes and tourist attractions: UiTM undergraduate studies, in 6th International Research Symposium in Service Management, IRSSM-6 2015, 11-15 August 2015, UiTM Sarawak, Kuching, Malaysia.
[3] Aris, NAM, Din, J 2012, 'Rain height statistics from spaceborne radar for satellite communication in Malaysia', Jurnal Teknologi, vol. 58(SUPPL.1), pp. $1-5$.

[4] Azlan, MAN, Din, J, Lam, HY 2011, 'Rain height information from TRMM precipitation radar for satellite communication in Malaysia', in 2011 IEEE International Conference on Space Science \& Communication: "Towards exploring the equatorial phenomena”, Proceedings 6015855, pp. $73-76$

[5] Azmy, MM, Hashim, M, Numata, S 2016, 'Satellitebased characterization of climatic conditions 
before large-scale general flowering events in Peninsular Malaysia', Sci. Reports, vol. 6, 32329.

[6] Chen, F, Liu, Y, Liu, Q, Li, X 2014, 'Spatial downscaling of TRMM $3 \mathrm{~B} 43$ precipitation considering spatial heterogeneity', Int. J. Remote Sens., vol. 35, pp. 3074-3093.

[7] Frankhauser, S 2016, Adaptation to climate change, Centre for Climate Change Economics and Policy Working Paper, No. 287, Grantham Research Institute on Climate Change and the Environment, Working Paper No. 255.

[8] Hashim, M, M. Reba, MN, Nadzri, MI, Pour, AB, Mahmud, MR, Mohd Yusoff, AR, Ali, MI, Jaw, SW, Hossain, MS 2016, 'Satellite-based run-off model for monitoring drought in Peninsular Malaysia', Remote Sens., vol. 8, no. 8, p.633.

[9] Hou, AY, RK, Kakar, S, Neeck, AA, Azarbazin, CD, Kummerow, M, Kojima, R, Oki, K, Nakamura, and T, Iguchi 2014, 'The global precipitation measurement mission', Bull. Amer. Meteor. Soc., vol. 95 , pp. 701-722. doi:10.1175/BAMS-D-13-00164.1.

[10] Huffman, GJ, Adler, RF, Arkin, P, Chang, A, Ferraro, R, Gruber, A, Janowiak, J, Rudolf, B, McNab, A, and Schneider, U 1997, 'The Global Precipitation Climatology Project (GPCP) combined precipitation dataset', Bull. Amer. Meteor. Soc., vol. 78, pp. 5-20.

[11] Huey, TT, Ibrahim, AL 2012, 'Statistical analysis of annual rainfall patterns in Peninsular Malaysia using TRMM algorithm, in 33rd Asian Conference on Remote Sensing 2012, 3, pp. 2681-2687.

[12] Ibrahim, S, Sahlan, Nor Shahida, Singh, MSJ 2016, 'Study on precipitation and its relation to pressure and temperature phenomenon over Malaysia during the ENSO phenomenon', Jurnal Kejuruteraan, vol. 28, pp. 53-64.

[13] Iguchi, T, R, Meneghini, J, Awaka, T, Kozu, and K, Okamoto 2000a, Rain profiling algorithm for TRMM precipitation radar data: Remote Sensing and Applications: Earth, Atmosphere and Oceans, vol. 25 , pp. 973-976.

[14] Iguchi, Toshio, Toshiaki Kozu, Robert Meneghini, Jun Awaka, Ken'ichi Okamoto 200ob, 'RainProfiling Algorithm for the TRMM Precipitation Radar', Journal of Applied Meteorology, vol. 39, no. 12, pp. 2038-2052.

[15] International Telecommunication Union (ITU) 2015, Propagation data and prediction methods required for the design of Earth-space telecommunication systems, Recommendation ITU-R, P.618-12, P Series, Radiowave Propagation.

[16] Isiaka, OYA, Khamis, NHH 2015, 'Seasonal and diurnal variability of rain heights at an equatorial station', Int. J. Electrical and Computer Engineering, vol. 5, no. 5, pp.1134-1142.

[17] Jian F, Du, J, Xu, W, Shi, P, Li, M, Ming, X 2013, 'Spatial downscaling of TRMM data based on orographic effect and meteorological condition of mountainous region', Adv. Water Resour., vol. 61, pp. 42-50.

[18] Lee, M 2013, 'The reality of balancing tourism development and protecting the nature heritage of Langkawi Island, Malaysia', J. Ecotourism, vol. 12, no. 3, pp. 197-203.

[19] Omotosho, TV, Mandeep, JS, Abdullah, M 2014, 'Cloud cover, cloud liquid water and cloud attenuation at $\mathrm{Ka}$ and $\mathrm{V}$ bands over equatorial climate', Meteorological Applications, vol. 21, no. 3, pp. 777-785. 
[20] Omotosho, TV, Mandeep, JS, Abdullah, M, Adediji, AT 2013, 'Distribution of one-minute rain rate in Malaysia derived from TRMM satellite data', Annales Geophysicae, vol. 31, no. 11, pp. 20132022.

[21] Orlove, B 2005, 'Human adaptation to climate change: a review of three historical cases and some general perspectives', Environmental Science \& Policy, vol. 8, no. 6, pp. 589-6oo.

[22] Mahmud, MR, Hashim, M 2010, 'Determination of forest water yield in Malaysian tropical watershed using calibrated satellite-based rainfall data', in CSSR 2010-2010 International Conference on Science and Social Research, 5773895, pp. 798803.

[23] Mahmud, MR, Hashim, M 2011, 'Operational satellite-based watershed monitoring systems (SAWMOS) for large humid tropical catchment environment', in 2011 IEEE Colloquium on Humanities, Science and Engineering, 6163821, pp. 687-691.

[24] Mahmud, MR, S, Numata, H, Matsuyama, T, Hosaka, and M, Hashim 2014, 'Challenge and opportunities of space-based precipitation radar for spatio-temporal hydrology analysis in tropical maritime influenced catchment: Case study on the hilly tropical watershed of Peninsular Malaysia, in IOP Conf. Series: Earth and Environmental Science, 18, 012001.

doi:10.1088/1755 1315/18/1/012001.

[25] Mahmud, MR, Numata, S, Matsuyama, H, Hosaka, T, Hashim, M 2015, 'Assessment of effective seasonal downscaling of TRMM precipitation data in Peninsular Malaysia', Remote Sens., vol. 7, no. 4, pp. 4092-4111.
[26] Mahmud, MR, Matsuyama, H, Hosaka, T, Numata, S, Hashim, M 2015, 'Temporal downscaling of TRMM rain-rate images using principal component analysis during heavy tropical thunderstorm seasons', J. Hydrometeor., vol. 16, no. 5 , pp. 2264-2275.

[27] Mahmud, MR, Hashim, M, Matsuyama, H, Hosaka, T, Numata, S 2018, 'Spatial downscaling of satellite precipitation data in humid tropics using a site-specific seasonal coefficient', Water, vol. 10, p. 409.

[28] Nadzri, MI, Hashim, M 2013, 'Validation of satellite precipitation using TRMM recent products', in 34th Asian Conference on Remote Sensing 2013, 3, pp. 1992-1999.

[29] National Research Council of the National Academies 2006, 'Assessment of TRMM to date', in Assessment of the Benefits of Extending the Tropical Rainfall Measuring Mission, The National Academies Press.

[30] National Space Development Agency of Japan 2001, TRMM data users handbook

[31] Paska, J, Lau, AMS, Tan, ML, Tan, KC 2017, 'Evaluation of TRMM 3 B442 V7 product on extreme precipitation measurements over Peninsular Malaysia, in Proceedings of The International Society for Optical Engineering, 10421, 104210D.

[32] Patrick, M, Mah, YS, Putuhena, FJ, Wang, YC, Selaman, OS 2016, 'TRMM satellite algorithm estimates to represent the spatial distribution of rainstorms, in MATEC Web of Conferences, vol. 87,01006

[33] Ramli, MH, Ibrahim, AL 2018, 'Remote sensingbased water yield estimation of the Kelantan River Basin, Malaysia', ARPN Journal of Engineering 
and Applied Sciences, vol. 13, no. 6, pp. 22922300 .

[34] Rauniyar, SP, Protat, A, Kanamori, H 2017, 'Uncertainties in TRMM-Era multisatellite-based tropical rainfall estimates over the Maritime Continent', Earth and Space Science, vol. 4, no. 5, pp. 275-302.

[35] Sani, M, Ibrahim, AL, Huey, TT, Rahman, MZA 2010, 'Application of remote sensing and geographical information system (GIS) for reservoir water balance analysis', in 31st Asian Conference on Remote Sensing 2010, vol. 1, pp. 334-340.

[36] Semire, FA, Mohd-Mokhtar, R, Ismail, W 2012, 'Ground validation of space-borne satellite rainfall products in Malaysia', Adv. in Space Res., vol. 50, no. 9 , pp. 1241-1249.

[37] Semire, FA, Mohd-Mokhtar, R 2016, 'Evaluation of satellite retrieval algorithm to ground rainfall estimates over Malaysia', Mapan-Journal of Meteorology Society of India, vol. 31, no. 3, pp. $177-187$

[38] Simpson, J, C, Kummerow, WK, Tao, and RF, Adler 1996, 'On the Tropical Rainfall Measuring Mission (TRMM)', Meteorology and Atmospheric Physics, vol. 6o, pp. 19-36.

[39] Sorooshian, S, Gao, X, Hsu, K, Maddox, RA, Hong, Y, Gupta, HV, Imam, B 2002, 'Diurnal variability of tropical rainfall retrieved from Combined GOES and TRMM satellite information', J. Climate, vol. 15, no. 9, pp. 983-1001.

[40] Tait, PW, Hanna, EG 2015, 'A conceptual framework for planning systemic human adaptation to global warming', Int. J. of
Environmental Research and Public Health, vol. 12, pp. 10700-10722.

[41] Tangang, F, Liew, JN, Salimun, E, Sei, KM, Le, LJ, Muhamad, H 2012, 'Climate change and variability over Malaysia', Sains Malaysiana, vol. 41, no. 11, pp. $1355^{-1366 . ~}$

[42] Varikoden, H, Samah, AA, Babu, CA 2010, 'Spatial and temporal characteristics of rain intensity in the peninsular Malaysia using TRMM rain rate', Journal of hydrology, 387 (3-4), pp. 312-319.

[43] Yusuff, AIO, Khamis, NHH 2013, 'Comparison of slant path rain attenuation models using data from a tropical station', in RFM 2013-2013 IEEE International $R F$ and Microwave Conference Proceedings, 6757255, pp. 228-233.

[44] Zad, SNM, Zulkafli, Z, Muharram, FM 2018, 'Satellite rainfall (TRMM 3B42-V7) performance assessment and adjustment over Pahang river basin, Malaysia', Remote Sensing, vol. 10, no. 3, p. 388.

[45] Zin, WZW, Jamaludin, S, Mohd Deni, S, Jemain, AA 2010, 'Recent changes in extreme rainfall events in Peninsular Malaysia: 1971-2005', Theo. \& App. Clim., vol. 99, p. 303. 